$$
\text { CONF-961178--3 }
$$

\title{
Photovoltaic Module and Array Performance Characterization Methods for All System Operating Conditions
}

\author{
David L. King \\ Sandia National Laboratories \\ Photovoltaic Systems Department, MS0752 \\ Albuquerque, NM 87185
}

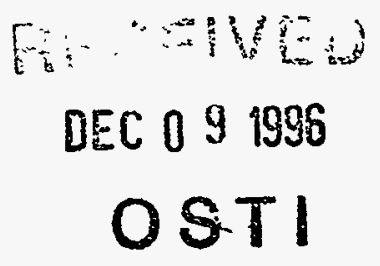

\begin{abstract}
This paper provides new test methods and analytical procedures for characterizing the electrical performance of photovoltaic modules and arrays. The methods use outdoor measurements to provide performance parameters both at standard reporting conditions and for all operating conditions encountered by typical photovoltaic systems. Improvements over previously used test methods are identified, and examples of the successful application of the methodology are provided for crystalline- and amorphous-silicon modules and arrays. This work provides an improved understanding of module and array performance characteristics, and perhaps most importantly, a straight-forward yet rigorous model for predicting array performance at all operating conditions. For the first time, the influences of solar irradiance, operating temperature, solar spectrum, solar angle-of-incidence, and temperature coefficients are all addressed in a practical way that will benefit both designers and users of photovoltaics.
\end{abstract}

\section{INTRODUCTION}

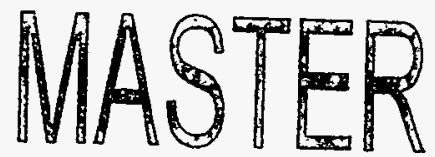

This work was motivated by a desire to improve the accuracy and versatility of methods currently used for characterizing the performance of photovoltaic arrays in their actual use environment. These improvements will enhance industry's ability to design systems that meet performance specifications, to rate system performance after installation, and to continuously monitor performance over the system's life. In general, these improvements should accelerate the commercialization of photovoltaic systems.

The current ASTM standard method for testing the electrical performance of modules and arrays (1) has served the industry well, but is best suited for determining module performance at only one operating condition, the "Standard Reporting Condition." Unfortunately, the standard reporting condition is at a temperature $\left(25^{\circ} \mathrm{C}\right)$ unrepresentative of actual operating conditions where

This work was supported by the U.S. Department of Energy under contract DEAC04-94AL8500. 
$50{ }^{\circ} \mathrm{C}$ is more common. The ASTM method doesn't translate well to other operating conditions, doesn't address all factors involved in outdoor performance ratings, and is often considered no better than $\pm 10 \%$ accurate when applied in the field to large photovoltaic arrays.

The limited versatility of the ASTM method led utilities to define what they considered a more realistic procedure for specifying system performance based on a month-long evaluation period with measurements translated to a specified solar irradiance, ambient temperature, and wind speed $(2,3)$. This procedure gave performance at a realistic operating temperature, but resulted in regression analyses that were less accurate than desired and limited in their ability to distinguish the interactive influences of solar irradiance, solar spectrum, solar angle-of-incidence, temperature coefficients, degree of thermal equilibrium, ambient temperature, and wind speed.

Recently, a "performance index" has been proposed as a means for continuously monitoring PV system performance. The index would provide the ratio of actual power to predicted power on a continuous basis. The value of this index, however, is dependent on the accuracy of the model used for predicting array performance (4). Today, data acquisition systems are often used to continuously monitor performance of large systems, but up to $15 \%$ loss in array output can go undetected due to the limitations of the predictive models used to estimate the expected array performance. In addition, almost ten years of system monitoring has been required before reliability analysts can confidently detect degradation in power output as large as 1 to $2 \%$ per year (5).

The testing methods, analytical procedures, and performance model described in this paper are the result of over 15 years of experience in outdoor testing of photovoltaic cells, modules, and arrays at Sandia National Laboratories. The resulting methodology for characterizing electrical performance is believed to be a significant improvement over previous methods, has been successfully applied to a wide variety of modules, and is now being applied by Sandia and others during the acceptance testing of large systems. Our goal is to validate and document the method, and submit it for consideration as a new test standard.

This paper will first describe the new array performance model, then illustrate the technical concepts that have led to improvements in outdoor testing methods, and finally illustrate the use of the new methodology in characterizing the performance of crystalline-silicon and amorphous-silicon arrays.

\section{ARRAY PERFORMANCE MODEL}

Photovoltaic array (module) performance for an arbitrary operating condition can be described by Equations (1-5). The variables defining the operating condition are irradiance, cell temperature, absolute air mass, and solar angle-of-

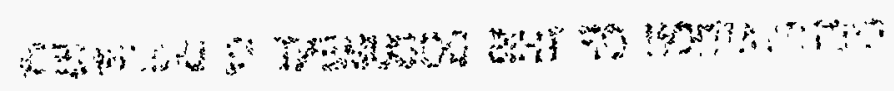




\section{DISCLAIMER}

This report was prepared as an account of work sponsored by an agency of the United States Government. Neither the United States Government nor any agency thereof, nor any of their employees, makes any warranty, express or implied, or assumes any legal liability or responsibility for the accuracy, completeness, or usefulness of any information, apparatus, product, or process disclosed, or represents that its use would not infringe privately owned rights. Reference herein to any specific commercial product, process, or service by trade name, trademark, manufacturer, or otherwise does not necessarily constitute or imply its endorsement, recommendation, or favoring by the United States Government or any agency thereof. The views and opinions of authors expressed herein do not necessarily state or reflect those of the United States Government or any agency thereof. 


\section{DISCLAMER}

Portions of this document may be illegible in electronic image products. Images are produced from the best available original document. 
incidence on the array. The equations for short-circuit current $\left(I_{s c}\right)$, maximumpówer current $\left(\mathrm{I}_{\mathrm{mp}}\right)$, open-circuit voltage $\left(\mathrm{V}_{\mathrm{oc}}\right)$, and maximum-power voltage $\left(\mathrm{V}_{\mathrm{mp}}\right)$ provide the four primary parameters from which others (fill factor, maximum power, efficiency) can be calculated. Equations (1,3, and 4) result in linear relationships closely related to the fundamental electrical characteristics of cells in the module. Equation (5) uses a second order relationship for $V_{m p}$ that implicitly contains the influences of factors such as module series resistance, wiring resistance, and non-ideal cell behavior at low light levels. Two additional empirical relationships, the "AM $\mathrm{A}_{\mathrm{a}}$ Function" and the "AOI-Function" are used to compensate for the influences of the solar spectrum and solar angle-of-incidence (AOI) on the short-circuit current. The terminology used in the equations is consistent with that used in ASTM standard methods for testing cells, modules, and arrays $(1,6,7)$.

A fundamental premise of this performance model is that the $I_{m p}, V_{m p}$, and $V_{o c}$ of a cell, module, or array are well behaved and predictable parameters when described as functions of $I_{s c}$ and cell temperature $\left(T_{c}\right)$ only. In other words, for a given $I_{s c}$ and $T_{c}$, the shape of the current-voltage (I-V) curve will be the same for any solar spectrum and angle-of-incidence. When this premise is valid, the performance characterization of a module or array becomes simply a matter of determining the short-circuit current, $\mathrm{I}_{\text {sco }}$, at a "reference operating condition," and then relating the other three performance parameters to this reference using the "effective irradiance" in Equation (2). One significant advantage of this approach is that compensating for the effects of solar spectrum and solar angle-of-incidence can be accomplished by adjusting only the $\mathrm{I}_{\mathrm{sc}}$ parameter, as in Equation (1).

$$
\begin{gathered}
I_{s c}\left(E, T_{c}, A M_{a}, A O I\right)=\left(E / E_{o}\right) f_{1}\left(A_{a}\right) f_{2}(A O I)\left\{I_{s c o}+\alpha_{I s c}\left(T_{c}-T_{o}\right)\right\} \\
E_{e}=I_{s c}\left(E, T_{c}=T_{o}, A M_{a}, A O I\right) / I_{s c o} \\
I_{m p}\left(E_{e}, T_{c}, A M_{a}, A O I\right)=E_{e}\left\{I_{m p o}+\alpha_{I m p}\left(T_{c}-T_{o}\right)\right\} \\
V_{o c}\left(E_{e}, T_{c}, A M_{a}, A O I\right)=V_{o c o}+C_{1} \ln \left(E_{e}\right)+\beta_{V_{o c}}\left(T_{c}-T_{o}\right) \\
V_{m p}\left(E_{e}, T_{c}, A M_{a}, A O I\right)=V_{m p o}+C_{2} \ln \left(E_{e}\right)+C_{3}\left\{\ln \left(E_{e}\right)\right\}^{2}+\beta_{V_{m p}}\left(T_{c}-T_{o}\right)
\end{gathered}
$$

Where:

$\mathrm{E}=$ Plane-of-array (POA) solar irradiance using broadband pyranometer

measurement corrected for angle-of-incidence sensitivity, $\mathrm{W} / \mathrm{m}^{2}$

$\mathrm{E}_{\mathrm{e}}=$ "Effective" irradiance, dimensionless, or "suns"

$\mathrm{E}_{\mathrm{o}}=$ Reference "one sun" irradiance in plane-of-array, $1000 \mathrm{~W} / \mathrm{m}^{2}$

$\mathrm{f}_{1}\left(\mathrm{AM}_{\mathrm{a}}\right)=$ Empirically determined " $A \mathrm{M}_{\mathrm{a}}$-Function" for solar spectral influence $\mathrm{f}_{2}(\mathrm{AOI})=$ Empirically determined "AOI-Function" for angle-of-incidence affects $\mathrm{AM}_{\mathrm{a}}=$ Absolute air mass 
AOI $=$ Solar angle-of-incidence on module, degrees

$\mathrm{I}_{\mathrm{sco}}=\mathrm{I}_{\mathrm{sc}}\left(\mathrm{E}=1000 \mathrm{~W} / \mathrm{m}^{2}, \mathrm{~T}_{\mathrm{c}}=\mathrm{T}_{\mathrm{r}}{ }^{\circ} \mathrm{C}, \mathrm{AM}_{\mathrm{a}}=1.5, \mathrm{AOI}=0^{\circ}\right)$

$\mathrm{I}_{\mathrm{mpo}}=\mathrm{I}_{\mathrm{mp}}\left(\mathrm{E}_{\mathrm{e}}=1, \mathrm{~T}_{\mathrm{c}}=\mathrm{T}_{0}{ }^{\circ} \mathrm{C}\right)$

$\mathrm{V}_{\text {oco }}=\mathrm{V}_{\text {oc }}\left(\mathrm{E}_{\mathrm{e}}=1, \mathrm{~T}_{\mathrm{c}}=\mathrm{T}_{\mathrm{o}}{ }^{\circ} \mathrm{C}\right)$

$\mathrm{V}_{\mathrm{mpo}}=\mathrm{V}_{\mathrm{mp}}\left(\mathrm{E}_{\mathrm{e}}=1, \mathrm{~T}_{\mathrm{c}}=\mathrm{T}_{0}{ }^{\circ} \mathrm{C}\right)$

$\mathrm{T}_{\mathrm{c}}=$ Temperature of cells inside module, ${ }^{\circ} \mathrm{C}$

$\mathrm{T}_{0}=$ Reference temperature for cells in module, e.g., 25 or $50^{\circ} \mathrm{C}$

$\alpha_{\mathrm{Isc}}=\mathrm{I}_{\mathrm{sc}}$ temperature coefficient, $\mathrm{A} /{ }^{\circ} \mathrm{C}$

$\alpha_{\text {Imp }}=I_{\text {mp }}$ temperature coefficient, $\mathrm{A} /{ }^{\circ} \mathrm{C}$

$\beta_{\mathrm{Voc}}=\mathrm{V}_{\mathrm{oc}}$ temperature coefficient, $\mathrm{V} /{ }^{\circ} \mathrm{C}$

$\beta_{\mathrm{V}_{\mathrm{mp}}}=\mathrm{V}_{\mathrm{mp}}$ temperature coefficient, $\mathrm{V} /{ }^{\circ} \mathrm{C}$

$\mathrm{C}_{1}=$ Empirically determined coefficient relating $\mathrm{V}_{\mathrm{oc}}$ to irradiance

$\mathrm{C}_{2}, \mathrm{C}_{3}=$ Empirically determined coefficients relating $\mathrm{V}_{\mathrm{mp}}$ to irradiance

The concept of "effective irradiance" is defined for photovoltaic devices in ASTM methods $(6,7)$ to account for the fact that the devices do not respond to all wavelengths of light contained in the solar spectrum. Thermopile-based pyranometers, like the Eppley PSP, measure the irradiance from the entire solar spectrum and are used for establishing the solar resource. Because power production from photovoltaic systems is based on this total solar resource, the concept of "effective irradiance" is used to describe the portion of the entire solar spectrum converted to electricity by the photovoltaic system. As used in this paper, the term is broadened to include not only the solar spectral influence, but also the optical effects related to solar angle-of-incidence. Thus, the effective irradiance, $E_{e}$, in Equation (2) depends on both the solar spectrum $\left(\mathrm{AM}_{\mathrm{a}}\right)$ and the influence of $\mathrm{AOI}$ on the $\mathrm{I}_{\mathrm{sc}}$.

This new approach for modeling array or module performance has several important features when compared to other methods. Some of these features are summarized as follows:

1. The model provides a well defined approach for obtaining an array performance "rating" at any user specified operating condition, not just the ASTM standard reporting condition.

2. The model provides a predictive model for array performance at all operating conditions, including the effects of solar spectrum and angle-of-incidence.

3. The model is easily implemented in a common spreadsheet.

4. All parameters required in the model can be determined through straight forward outdoor measurement procedures.

5. The fundamental electrical behavior of solar cells is preserved.

6. Temperature coefficients are handled in a more rigorous way with separate coefficients for $I_{s c}, I_{m p}, V_{o c}$, and $V_{m p}$.

7. The accuracy of performance "ratings" is improved by emphasizing the determination of a reference short-circuit current $\left(\mathrm{I}_{\mathrm{sco}}\right)$, and then relating the 
other parameters $\left(I_{m p}, V_{o c}, V_{m p}\right)$ to the ratio of the measured $I_{s c}$ and $I_{s c o}$. This approach preserves the inherent self-consistent electrical behavior of the cells.

8. Performance is related to cell temperature inside the modules $\left(T_{c}\right)$, rather than module temperature, thus compensating for the frequent situation. where modules are not in thermal equilibrium.

9. When designing or predicting performance of arrays, the model gives $\mathrm{I}_{\mathrm{sc}}$ in terms of the variable most readily available from solar resource databases, the irradiance, E, as measured by a thermopile-based pyranometer.

10. This model, coupled with a solar resource database, could provide a practical method for calculating a daily, monthly, or annual "energy rating" (8).

Prior to illustrating the application of this methodology in the performance characterization of two photovoltaic arrays, the next six subsections of this paper will discuss the technical improvements and concepts that are required to take full advantage of the new performance model. The topics discussed will include: improvements in irradiance measurements using pyranometers, relating solar spectral influence to absolute air mass, quantifying the influence of AOI, a more rigorous approach to applying temperature coefficients, a method for calculating the temperature of cells inside modules, and an empirical relationship relating module temperature to irradiance, wind speed, and ambient temperature.

\section{Solar Irradiance Measurements}

Historically, one of the largest errors in rating the performance of PV arrays has had nothing to do with the array itself. Rather, it has been due to a time-ofday dependent systematic error in measurements of the plane-of-array solar irradiance. The accuracy of an array performance rating is directly related to the accuracy of the solar irradiance measurement; therefore, systematic errors in irradiance measurements must be addressed as the first step in the rating process. The systematic error most often ignored in field performance measurements has been due to the influence of solar angle-of-incidence (AOI) on the response (calibration) of typical pyranometers. Academically this issue has been investigated $(9,10)$, but rarely are pyranometers calibrated as a function of AOI for general use.

Standard ASTM methods for calibrating pyranometers (11) typically result in a single "calibration number," often reported for an AOI $=45^{\circ}$. In addition, ASTM methods for reference cells $(6,7,12)$ result in a calibration that is valid only for normal incidence. Figure 1 illustrates the magnitude of the correction required in irradiance measurements as a function of AOI for a typical Eppley PSP pyranometer. The curve shown in Figure 1 was generated by curve fitting the results of an AOI-dependent calibration performed at Sandia. Clearly, the first step in improving the performance rating of modules or arrays is to obtain an AOI-dependent calibration of the pyranometer used for field measurements. 


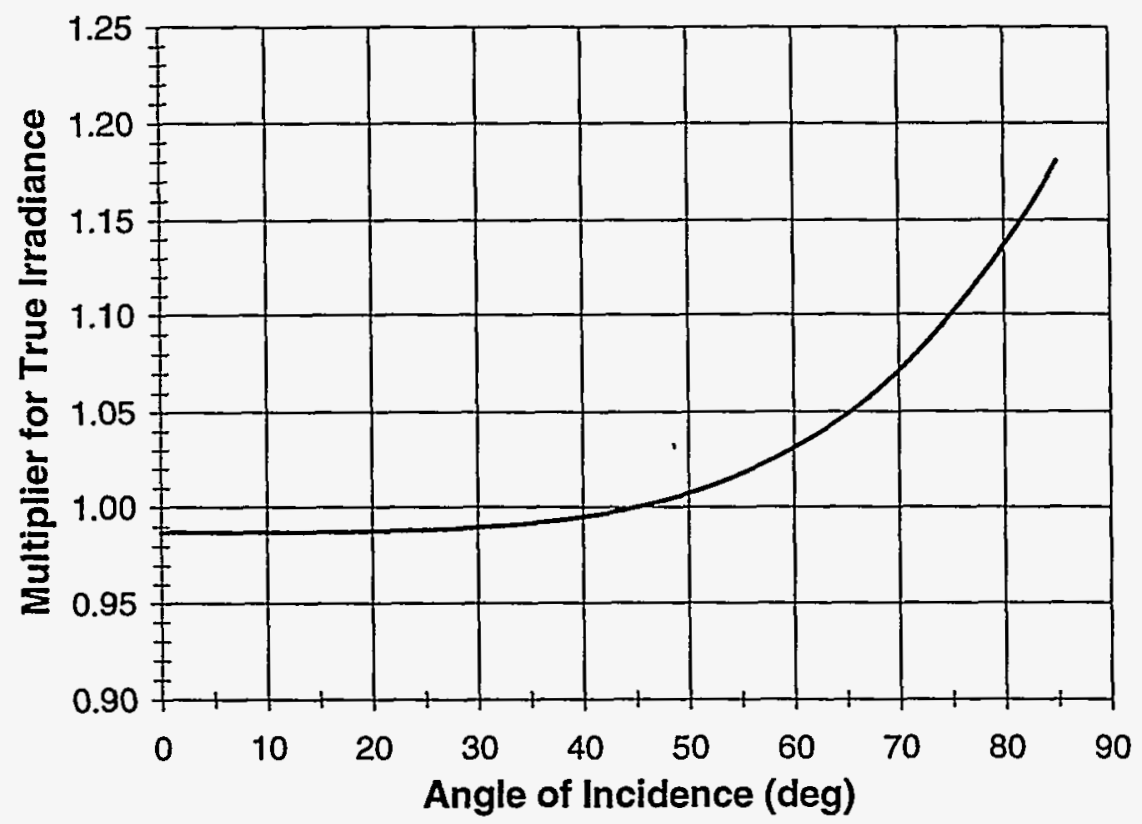

FIGURE 1. Influence of solar angle-of-incidence on the irradiance indicated by a typical Eppley PSP pyranometer.

\section{Influence of Solar Spectrum}

As previously discussed, the current generated by a solar cell is influenced by the spectral distribution (spectrum) of sunshine. This is common knowledge to people familiar with photovoltaic technology. However, the magnitude of this effect and the real significance of the effect on the daily or annual energy production by a photovoltaic system is not well understood. Atmospheric scientists point out that the solar spectrum is influenced by a large number of variables including: absolute air mass, precipitable water, turbidity, clouds, dust, smoke, other aerosols, ground albedo, etc. (13). Nonetheless, testing experience at Sandia has indicated that, for the clear sky conditions typically present during performance rating, the majority of the solar spectral influence can be accounted for by considering only the effect of air mass on $I_{s c}$.

The solar spectral effect can be empirically related to absolute air mass, resulting in the " $A M_{a}$ Function", $f_{1}\left(A M_{a}\right)$. This function is technology specific, depending on the spectral response of the module, and also site specific, depending on the site's atmospheric characteristics. For clear sky conditions, however, experience has shown that an $\mathrm{AM}_{\mathrm{a}}$ Function determined for a crystalline silicon module in Albuquerque (NM) has little seasonal variation, and has been successfully applied to array measurements in Globe (AZ), Lake Powell (UT), Barstow (CA), and Sacramento (CA). 
Air mass (AM) is the term used to describe the relative path length that the sun's rays have to traverse through the atmosphere before reaching the ground. An $A M=1$ condition occurs when the sun is directly overhead at a sea-level site; air mass values of 10 or greater occur near sunrise and sunset. Thus, air mass is a function of the position of the sun, which can be accurately calculated given site location, day of the year, and the time of day. To compensate for sites at altitudes other than sea level, the term "absolute air mass" $\left(\mathrm{AM}_{\mathrm{a}}\right)$ is used. The absolute air mass is obtained by simply multiplying AM by the ratio of the site's atmospheric pressure $(\mathrm{P})$ to that at sea level $\left(\mathrm{P}_{0}\right)$. If atmospheric pressure is not measured at the site, a simple exponential relationship used by the meteorological community can be used to calculate the pressure ratio using site altitude.

Equations (6-7) are commonly used for calculating the absolute air mass $\left(\mathrm{AM}_{\mathrm{a}}\right)$ as a function of $Z_{s}$, the solar zenith angle $(13,14)$.

$$
\begin{aligned}
& \mathrm{AM}=\left\{\cos \left(\mathrm{Z}_{\mathrm{s}}\right)+0.5057\left(96.080-\mathrm{Z}_{\mathrm{s}}\right)^{-1.634}\right\}^{-1} \\
& \mathrm{AM}_{\mathrm{a}}=\left(\mathrm{P} / \mathrm{P}_{0}\right) \mathrm{AM} \quad \text { where: } \mathrm{P}_{0}=760 \mathrm{~mm} \mathrm{Hg} \\
& P / P_{0} \approx e^{(-0.0001184 h)} \quad \text { where: } h=\text { altitude }(m)
\end{aligned}
$$

Figure 2 shows the relative short-circuit current $\left(\mathrm{AM}_{\mathrm{a}}\right.$ Function) for two different photovoltaic technologies, a Siemens (M55) crystalline-silicon module and a USSC (UPM-880) tandem amorphous-silicon module. Data in Figure 2 were measured with the modules on a solar tracker pointed normal to the sun from sunrise until sunset. The measured $\mathrm{I}_{\mathrm{sc}}$ was translated to $50^{\circ} \mathrm{C}$ and normalized to $1000 \mathrm{~W} / \mathrm{m}^{2}$ using the irradiance as measured with an Eppley PSP pyranometer adjacent to the module. The thermopile detector in the Eppley pyranometer provided a spectrally-independent measurement of the total solar irradiance, $\mathrm{E}$. Polynomial fits to the measured data provide the "AMa-Functions" that can be used in analyzing field performance measurements. These empirical functions are easily determined, requiring only a small solar tracker, a thermopile-based pyranometer, and a single solar cell with spectral response identical to those in the array being analyzed.

The $\mathrm{AM}_{\mathrm{a}}$ Function as used in the new model is straight forward to measure, widely applicable, and easily modeled knowing only the zenith angle of the sun and site altitude. Nonetheless, other analysts may desire to more rigorously model atmospheric effects and the resulting effect on $\mathrm{I}_{\mathrm{sc}}$. If this is done, the function $f_{l}\left(A M_{a}\right)$ in Equation (1) can simply be replaced, and the remainder of the performance model is still applicable. A specific example occurs when a reference cell is used to determine the reference $I_{\text {sco }}$ for a site where the solar spectrum present at the $\mathrm{AM}_{\mathrm{a}}=1.5$ condition differs significantly from the ASTM standard spectrum (14). In this case, the solar spectral irradiance occurring at 
$\mathrm{AM}_{\mathrm{a}}=1.5$ is measured with a spectral radiometer, and a spectral mismatch correction is calculated using a standard ASTM method (15). Including the spectral mismatch correction as part of the $f_{1}\left(A_{a}\right)$ function will then relate measured performance back to the ASTM Standard Reporting Condition (1).

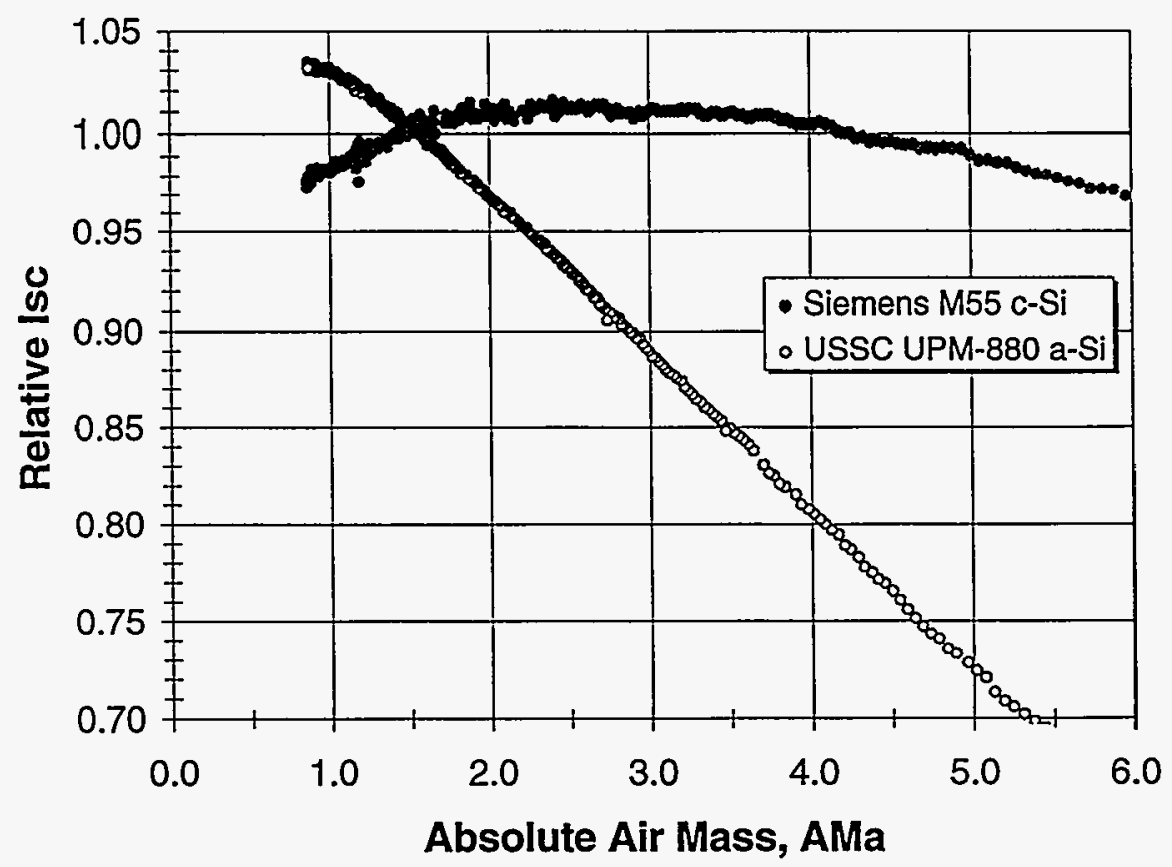

FIGURE 2. "AM $\mathrm{M}_{\mathrm{a}}$ Functions" showing the influence of absolute air mass on $I_{\mathrm{sc}}$ for a Siemens (M55) crystalline-silicon module and a USSC (UPM-880) tandem amorphoussilicon module.

\section{Influence of Solar Angle-of-Incidence}

Photovoltaic modules have an AOI-dependent optical behavior that can be measured and used to improve the analysis of array performance. Like absolute air mass, solar angle-of-incidence is time-of-day dependent. Its affect on the short-circuit current $\left(I_{\mathrm{sc}}\right)$ of a photovoltaic module results from two causes. The first is familiar to solar enthusiasts as the "cosine effect." The "cosine effect" is independent of the module design, and is only geometry related. Due to the cosine effect, the $\mathrm{I}_{\mathrm{sc}}$ from a module varies directly with the cosine of the AOI. For example, at $\mathrm{AOI}=60^{\circ}$ the cosine effect reduces $\mathrm{I}_{\mathrm{sc}}$ by one half compared to the normal incidence condition. The second way $I_{s c}$ is affected by AOI is dependent on the module design. The optical characteristics of the module materials located between the sun and the solar cells cause the effect. For example, flat-plate modules typically have glass front surfaces; the dominant contributor to the 
"optical effect" in this case is reflectance from the front surface of the glass. This reflectance increases significantly for AOI greater than about 50 degrees.

Two different testing procedures can be used to measure these AOI-dependent influences on module performance. The first procedure uses POA irradiance measurements to remove the cosine effect and results in an empirical "AOIFunction" that quantifies only the "optical effect." The second procedure uses total (global) normal irradiance measurements and results in an alternative empirical function that contains both the cosine effect and the optical effect.

Figure 3 illustrates the "optical effect" measured for a typical ASE Americas (ASE-300-DG/50) crystalline-silicon module. A polynomial fit to the normalized $I_{\text {sc }}$ shown in the figure provides an "AOI Function" that can be applied in Equation (1). The measured data shown in Figure 3 were obtained at Sandia under clear sky conditions when the ratio of the direct normal irradiance (DNI) to total normal irradiance (TND) was greater than 0.9. The measurements were made with the module on a computer-controlled solar tracker where AOI could be varied over a wide range in a short period of time, thus removing solar spectral influence from the data. The measured $\mathrm{I}_{\mathrm{sc}}$ was translated to $50^{\circ} \mathrm{C}$, normalized to $1000 \mathrm{~W} / \mathrm{m}^{2}$ using POA irradiance, and then divided by the $I_{\mathrm{sc}}$ obtained at normal incidence. The pyranometer used to measure POA irradiance was calibrated as a function of AOI and provided the "true" irradiance on the module. The second relationship in Figure 3 describing the combined cosine and optical effects was measured during the same test, the difference being that the $\mathrm{I}_{\mathrm{sc}}$ was normalized using the total normal irradiance measured by a pyranometer on a separate tracker.

An additional clarification is perhaps needed here. The AOI Functions illustrated in Figure 3 are also dependent on the "clearness" of the sky, having the largest influence on $\mathrm{I}_{\mathrm{sc}}$ for test conditions where the ratio DNI/TNI is high. The clear sky situation is usually considered a prerequisite when conducting an outdoor rating of a module or array, so the functions are applicable. The opposite extreme occurs for a very overcast sky with perfectly diffuse illumination of the array; in this case, AOI has no influence whatsoever on the array's $I_{s c}$. Therefore, when the model is used for predicting array performance for a site with a diffuse solar resource, an additional relationship may be needed to diminish the optical effect measured under clear conditions.

\section{Calculating Solar Angle-of-Incidence}

The solar angle-of-incidence on a module can be calculated using Equation (9). The values required in the equation are the azimuth and zenith angles defining the position of the sun $\left(A Z_{\mathrm{s}}, Z_{\mathrm{s}}\right)$ and two angles that define the orientation of the module or array $\left(A Z_{m}, T_{m}\right)$.

$$
\mathrm{AOI}=\cos ^{-1}\left\{\cos \left(\mathrm{T}_{\mathrm{m}}\right) \cos \left(\mathrm{Z}_{\mathrm{s}}\right)+\sin \left(\mathrm{T}_{\mathrm{m}}\right) \sin \left(\mathrm{Z}_{\mathrm{s}}\right) \cos \left(\mathrm{AZ}_{\mathrm{s}}-\mathrm{AZ}_{\mathrm{m}}\right)\right\}
$$


Where:

AOI = solar angle of incidence (deg)

$T_{\mathrm{m}}=$ tilt angle of module (deg) $\left(0^{\circ}\right.$ is horizontal)

$Z_{s} \quad=$ zenith angle of sun (deg)

$\mathrm{AZ}_{\mathrm{m}}=$ azimuth angle of module $\left(0^{\circ}=\right.$ North, $90^{\circ}=$ East $)$

$A Z_{s}=$ azimuth angle of sun $\left(0^{\circ}=\right.$ North, $90^{\circ}=$ East $)$

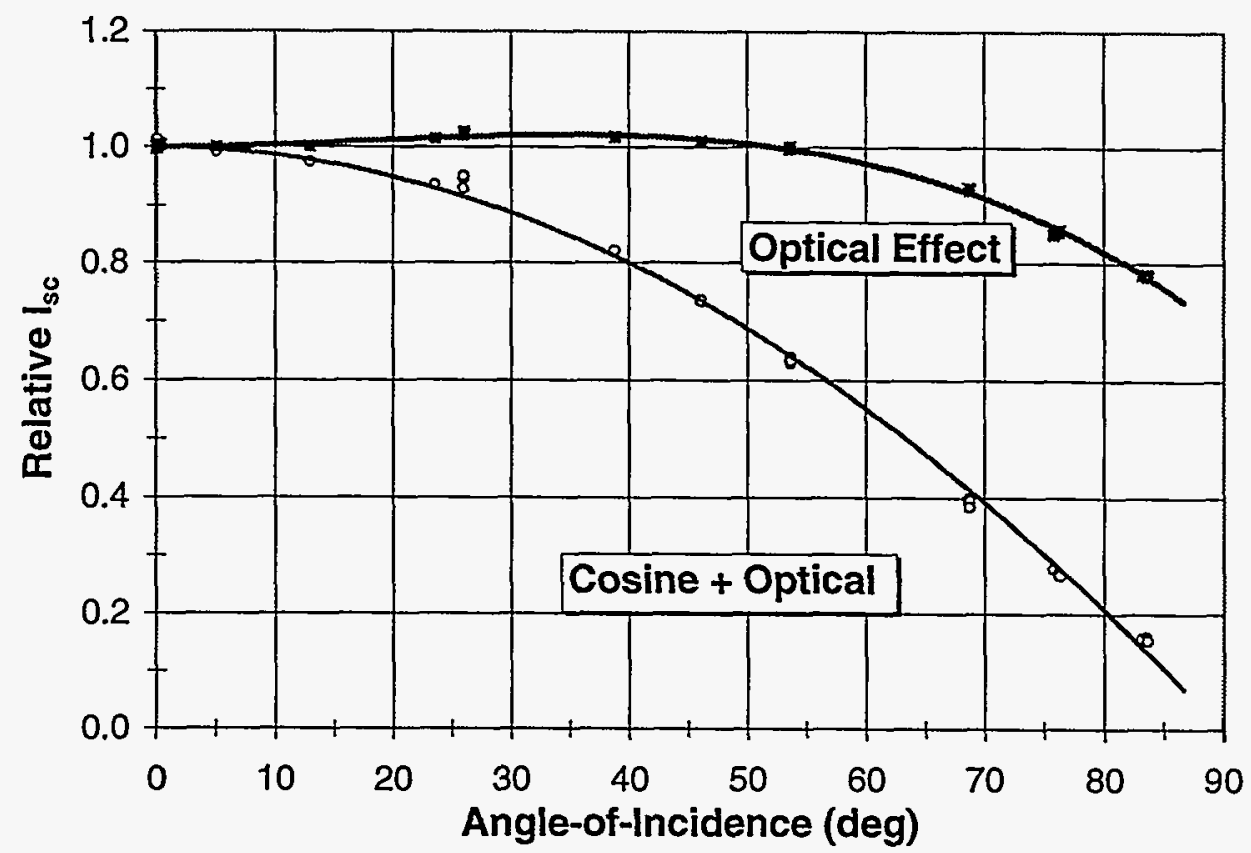

FIGURE 3. "AOI Functions" showing influence of solar angle-of-incidence on $I_{s c}$ for an ASE Americas (ASE-300-DG/50) module.

\section{Temperature Coefficients}

Current ASTM standard methods make the assumption that all points on a measured current-voltage (I-V) curve can be translated to a different operating temperature by applying two temperature coefficients, one for current and one for voltage. Cell and module testing at Sandia has confirmed that this assumption is often invalid, and is one of the reasons that the $\mathrm{I}-\mathrm{V}$ translation equations defined by ASTM (1) are less accurate than desired. For example, Table 1 gives the temperature coefficients measured at Sandia on four different commercial photovoltaic modules. The table illustrates that the coefficients at the maximum power condition can be significantly different from those at open-circuit and 
short-circuit. This observation led to the use of four separate temperature coefficients in the performance model defined by Equations (1-4).

TABLE 1. Measured temperature coefficients for typical commercial modules at ASTM Standard Reporting Conditions (1).

\begin{tabular}{|cccccc|}
\hline Module & $\begin{array}{c}\mathrm{dl}_{\mathrm{s}} \mathrm{d} \mathrm{dT} \\
\left(\mathrm{A} /{ }^{\circ} \mathrm{C}\right)\end{array}$ & $\begin{array}{c}\mathrm{dl}_{\mathrm{mp}} / \mathrm{dT} \\
\left(\mathrm{A} /{ }^{\circ} \mathrm{C}\right)\end{array}$ & $\begin{array}{c}\mathrm{dV}_{\mathrm{o} d \mathrm{dT}} \\
\left(\mathrm{V} /{ }^{\circ} \mathrm{C}\right)\end{array}$ & $\begin{array}{c}\mathrm{dV}_{\mathrm{mm}} / \mathrm{dT} \\
\left(\mathrm{V} /{ }^{\circ} \mathrm{C}\right)\end{array}$ & $\begin{array}{c}\mathrm{dP}_{\mathrm{mp}} / \mathrm{dT} \\
\left(\mathrm{W} /{ }^{\circ} \mathrm{C}\right)\end{array}$ \\
\hline ASE-300-DG/50 & +.0059 & +.0021 & -0.23 & -0.24 & -1.3 \\
Siemens M55 & +.0013 & +.0001 & -.084 & -.085 & -.25 \\
Solarex MSX-64 & +.0022 & +.0002 & -.085 & -.086 & -.29 \\
USSC UPM-880 & +.0014 & +.0024 & -.085 & -.061 & -.044 \\
\hline
\end{tabular}

The module temperature coefficients for $\mathrm{I}_{\mathrm{sc}}, \mathrm{I}_{\mathrm{mp}}, \mathrm{V}_{\mathrm{oc}}$, and $\mathrm{V}_{\mathrm{mp}}$ were measured at Sandia under outdoor conditions with high and stable solar irradiance $(\sim 1000$ $\left.\mathrm{W} / \mathrm{m}^{2}\right)$, clear sky, and low wind speed $(<2 \mathrm{~m} / \mathrm{s})$. Wind speeds above $2 \mathrm{~m} / \mathrm{s}$ tend to increase the magnitude of the voltage coefficients measured. The module was first

shaded until near ambient temperature was achieved, as indicated by multiple thermocouples attached to the back surface of the module. Then the module was quickly uncovered and I-V curves and temperature were measured every 20 seconds until the module reached its operating temperature (10 to 40 minutes depending on module design). Regression analysis was used to determine each of the four temperature coefficients.

The temperature coefficient for $\mathrm{P}_{\mathrm{mp}}$ in Table 1 was calculated rather than measured directly. $\mathrm{P}_{\mathrm{mp}}$ is the product of $\mathrm{I}_{\mathrm{mp}}$ and $\mathrm{V}_{\mathrm{mp}}$. Therefore, Equation (10) must be used to calculate this coefficient by using the temperature coefficients for $I_{m p}$ and $V_{m p}$ and the values for $V_{m p}$ and $I_{m p}$ at ASTM standard reporting conditions. The temperature coefficient for $\mathrm{P}_{\mathrm{mp}}$ varies with both irradiance level and module temperature. As a result, the common practice of assuming a constant $\mathrm{P}_{\mathrm{mp}}$ temperature coefficient should be used with caution. The $-0.5 \% / \mathrm{C}$ value often used for crystalline silicon modules is only valid at $1000 \mathrm{~W} / \mathrm{m}^{2}$ irradiance and an operating temperature of $25^{\circ} \mathrm{C}$. Figure 4 dramatically illustrates this point for a tandem amorphous silicon module manufactured by United Solar Systems Corporation. At standard reporting conditions the module has a negative power coefficient of about $-0.3 \% /{ }^{\circ} \mathrm{C}$, but at cold low irradiance conditions the coefficient is positive, about $+1.5 \% /{ }^{\circ} \mathrm{C}$ ! A similar but less dramatic behavior is illustrated in Figure 5 for a crystalline silicon module.

To analyze array performance data, temperature coefficients appropriate for the entire array are required. Using predetermined temperature coefficients for modules, the array coefficients for voltage are determined by multiplying the module value by the number of modules connected in series in a module-string, and the array current coefficients are determined by multiplying the module value by the number of module-strings connected in parallel. 


$$
\mathrm{dP}_{\mathrm{mp}} / \mathrm{dT}=\mathrm{V}_{\mathrm{mp}}\left(\mathrm{dI}_{\mathrm{mp}} / \mathrm{dT}\right)+\mathrm{I}_{\mathrm{mp}}\left(\mathrm{dV}_{\mathrm{mp}} / \mathrm{dT}\right)
$$

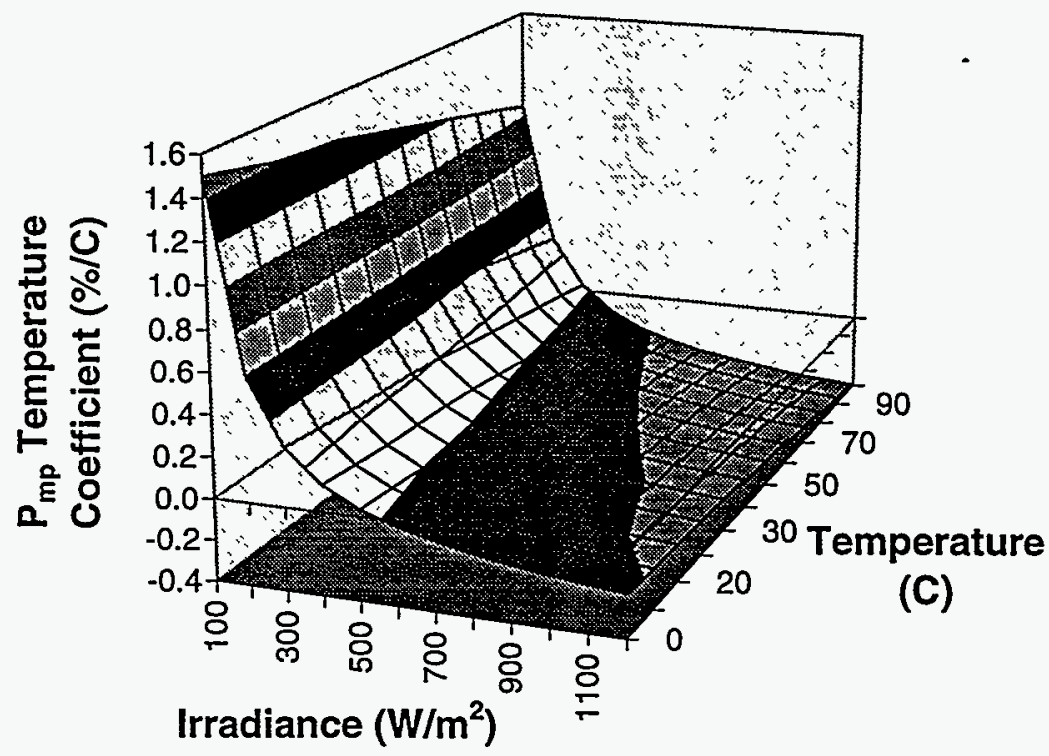

FIGURE 4. Temperature coefficient for $P_{m p}$ for a USSC UPM- 880 tandem amorphous silicon module as a function of irradiance and cell temperature.

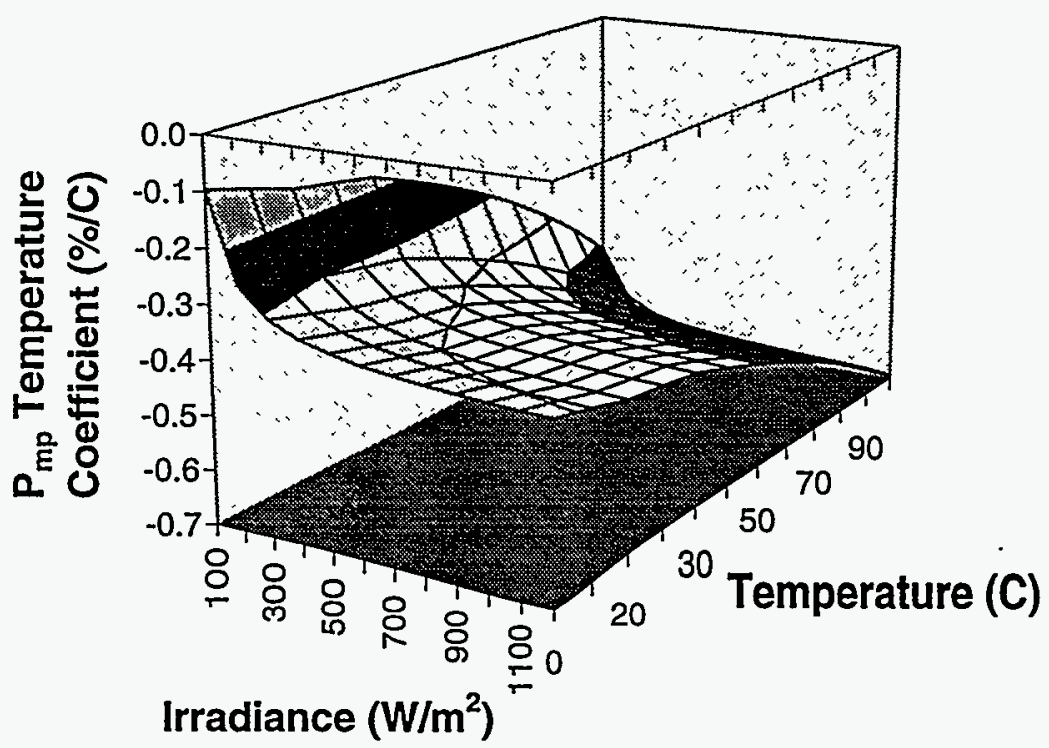

FIGURE 5. Temperature coefficient for $P_{m p}$ for an ASE Americas ASE-300-DG/50 module as a function of irradiance and cell temperature. 


\section{Calculated Cell Témperature}

Back-surface module temperatures are straight forward to measure, but they are not the best value to use in array performance characterization. The problem with using back-surface temperature is that the temperature difference between the back surface and the cell itself is neglected. This temperature difference arises from two factors: a temperature drop from the cell to back surface due to the thermal conductivity of materials between, and the frequent lack of thermal equilibrium in the outdoor environment. Lack of thermal equilibrium results from cloud passage, sunrise or sunset transitions, or sudden changes in wind speed or wind direction. One way to address these factors is to use a "calculated cell temperature" based on module $I_{s c}$ and $V_{o c}$, with the calculated value referenced to a known temperature when the module is in thermal equilibrium. A distinct advantage of this approach is that the calculated value provides an essentially instantaneous cell temperature, free of the time lag associated with the mass of the module. Thus, the bias errors in module performance measurements introduced by non-equilibrium conditions are avoided. The concept of calculated cell temperature is also used in commercial devices (ESTI sensors) used for measuring solar irradiance (17), and has been proposed as an alternative to actual temperature measurements during module testing (18).

Figure 6 illustrates an example of calculated cell temperature using data obtained during performance characterization of a $25-\mathrm{kW}$ array of ASE Americas modules used in a telecommunications system located near Globe, AZ. By comparing the back-surface module temperature with the calculated cell temperature, it was determined that it took about 2.5 hours after sunrise for the array to reach quasi-thermal equilibrium. The equilibrium condition was maintained for about 2 hours until intermittent cloud cover occurred.

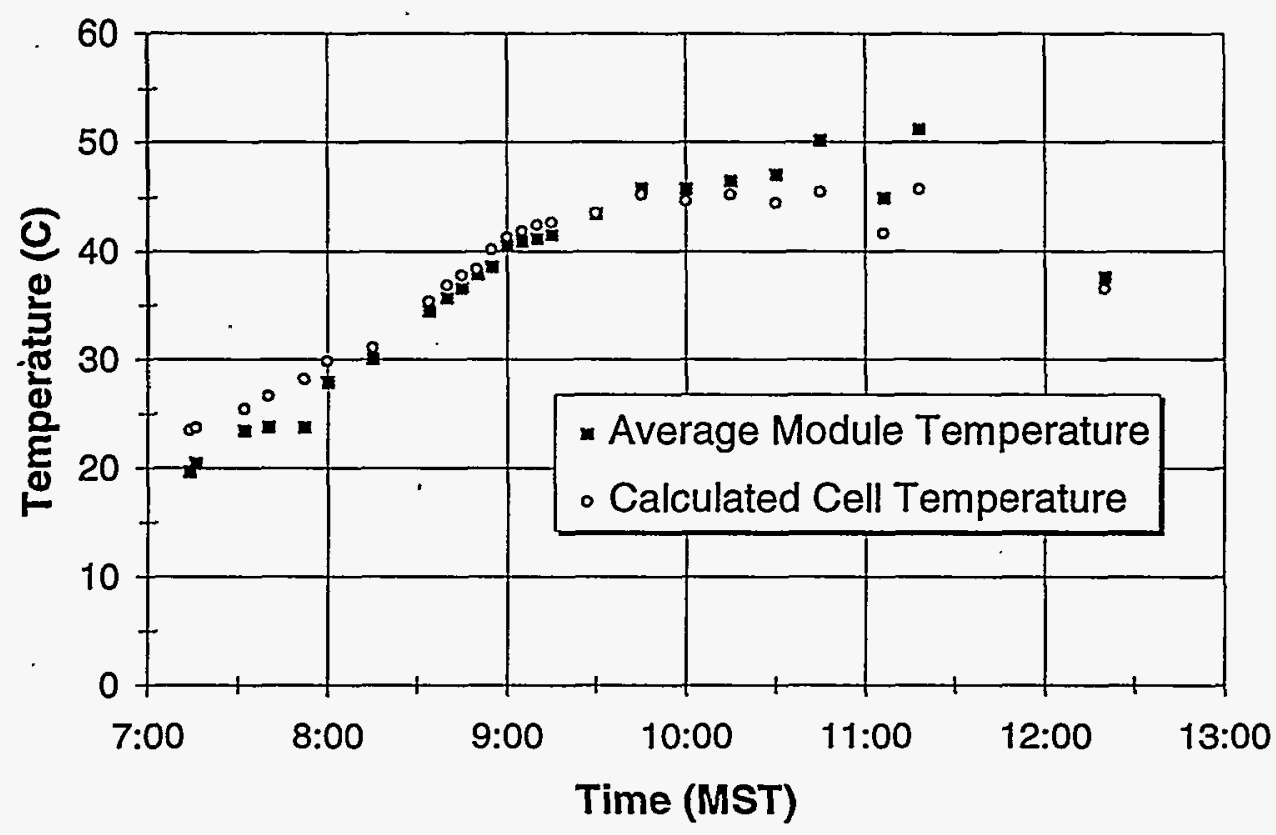

FIGURE 6. Calculated cell temperatures and module back-surface temperatures for a 25-kW array of ASE Americas (ASE-300-DG/50) modules tested on 9/25/95. 
The relationship used to determine the "calculated cell temperature," $T_{c}$, is obtained by solving for $T_{c}$ in Equation (11). Basically, this equation gives an estimate of the average temperature for all the cells in the array. The reference values for $I_{s c r}, V_{o c r}$, and $T_{r}$ are determined when the array is judged to be in a thermal equilibrium. In thermal equilibrium, the back surface temperature of the module can be used as a close approximation of the cell temperature, or an offset can be introduced to compensate for the small temperature gradient typically present between the back surface and the cell. Typical flat-plate crystalline silicon modules, in thermal equilibrium at $1000 \mathrm{~W} / \mathrm{m}^{2}$ irradiance and less than $3 \mathrm{~m} / \mathrm{s}$ wind speed, usually have a cell temperature 2 to $3{ }^{\circ} \mathrm{C}$ higher than the back surface.

$$
\mathrm{V}_{o d} / \mathrm{N}=\mathrm{V}_{\text {ocr }} \mathbb{N}+\left(n k T_{d} / \mathrm{q}\right) \ln \left(\mathrm{I}_{\mathrm{sc}} / \mathrm{I}_{\mathrm{scr}}\right)+\beta_{\mathrm{voc}}\left(\mathrm{T}_{\mathrm{c}}-\mathrm{T}_{\mathrm{r}}\right)
$$

Where:

$\mathrm{N}=$ Total number of cells connected in series in the array

$\mathrm{I}_{\mathrm{sc}} \quad$ = Measured array short-circuit current, (A)

$\mathrm{V}_{\mathrm{oc}}=$ Measured array open circuit voltage, $(\mathrm{A})$

$I_{\text {scr }}=$ Array short-circuit current at the reference temperature, (A)

$\mathrm{V}_{\text {ocr }}=$ Array open-circuit voltage at the reference temperature, $(\mathrm{A})$

$\mathrm{T}_{\mathrm{c}} \quad=$ Temperature of cells inside module, $(\mathrm{K})$

$\mathrm{T}_{\mathrm{r}} \quad=$ Reference temperature for cells, $(\mathrm{K})$

$\beta_{\mathrm{Voc}}=$ Temperature coefficient for $\mathrm{V}_{\mathrm{oc}}$ for individual cell, $\left(\mathrm{V} /{ }^{\circ} \mathrm{C}\right)$

$\mathrm{n} \quad=$ Cell diode factor ( $\mathrm{n}=1$ can be assumed for typical silicon cells)

$\mathrm{k}=$ Boltzmann's constant, $(1.38066 \mathrm{E}-23 \mathrm{~J} / \mathrm{K})$

$\mathrm{q}=$ Elementary charge, $(1.60218 \mathrm{E}-19 \mathrm{C})$

\section{Module Operating Temperature}

One final relationship is needed to make the performance model given by Equations (1-5) useful for system design and performance predictions prior to installation of an array. This relationship relates module temperature to the environmental variables typically available for system sizing calculations (solar irradiance, ambient temperature, and wind speed). Unfortunately, determining this relationship accurately is difficult because it depends not only on module design, but on mounting configuration (open rack or roof-integrated), wind direction, thermal radiation, and degree of thermal equilibrium. Figure 7 illustrates an empirically determined relationship for an ASE Americas module using measurements obtained over several months at Sandia. For example, at $800-\mathrm{W} / \mathrm{m}^{2}$ irradiance and $1-\mathrm{m} / \mathrm{s}$ wind speed and ambient temperature of $20^{\circ} \mathrm{C}$, the module temperature is given as $44^{\circ} \mathrm{C}$. The data were screened to eliminate cloud transient effects, and thus represent near thermal equilibrium conditions. 
Although some work has been documented on the topic (19), module manufacturers and/or system designers will need to determine similar relationships for other module types and mounting configurations. On a positive note, if module operating temperature can be calculated within $\pm 5^{\circ} \mathrm{C}$, then the resulting uncertainty in predicted power output should be less than $3 \%$.

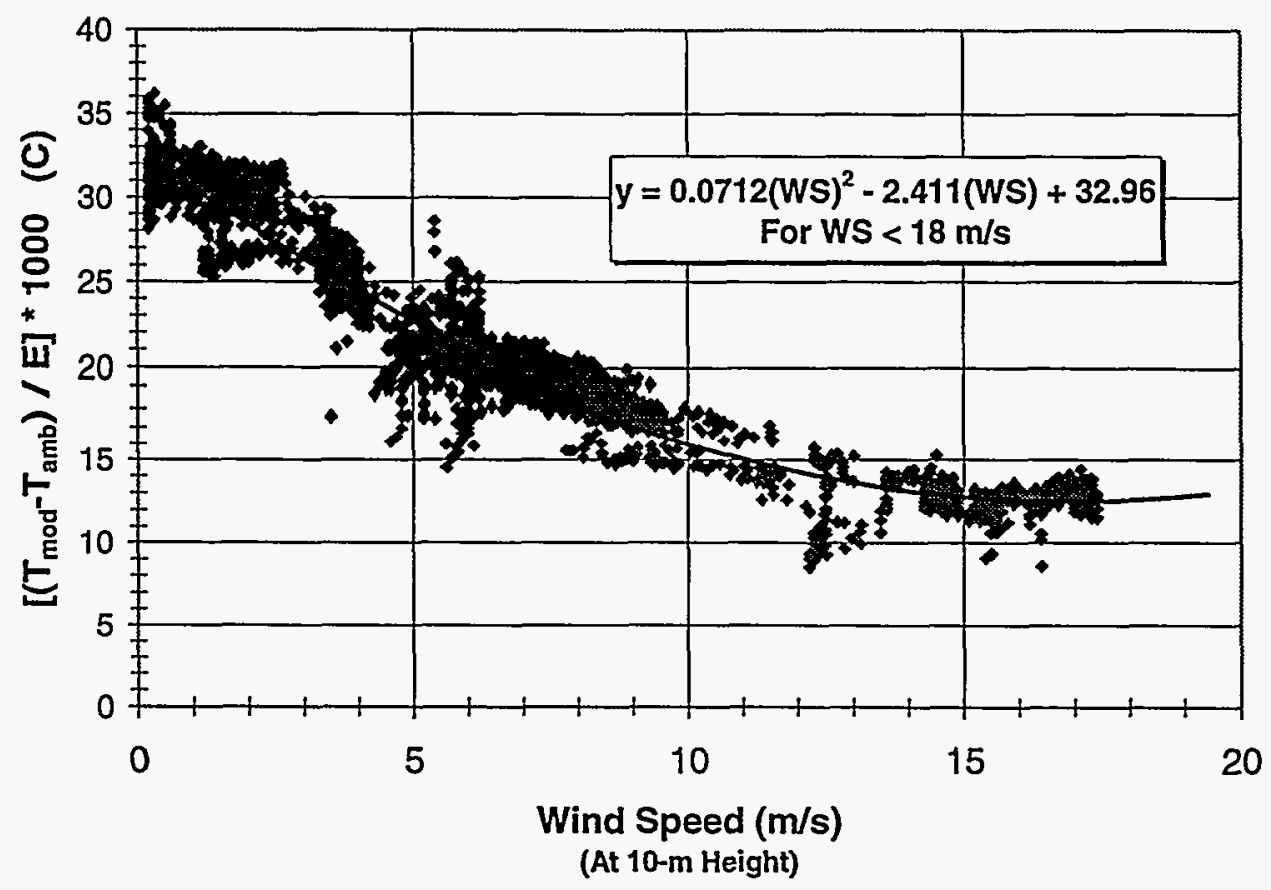

FIGURE 7. Empirical relationship providing module temperature, $T_{\text {mod, }}$ as a function of ambient temperature, $T_{\text {amb }}$, POA irradiance $(E)$, and wind speed for an ASE-300-DG/50 module mounted in an open rack.

\section{APPLICATION OF METHODOLOGY}

The performance model and testing procedures previously discussed have been applied by Sandia to a wide variety of commercially available photovoltaic modules with good success. The methodology has also been applied during the performance rating of large arrays. To illustrate the accuracy and versatility of the methodology, the results of its application for two distinctly different photovoltaic arrays have been be provided. The first $25-\mathrm{kW}$ array, owned by Arizona Public Service Company, was composed of 90 ASE-300-DG/50 modules configured in 15 parallel module-strings with 6 series connected modules in each. The second $1.3-\mathrm{kW}$ roof-integrated array, owned by the Sacramento Municipal Utility District, was composed of 96 USSC triple-junction amorphous-silicon modules (shingles) configured in 16 parallel module-strings with 6 series connected modules in each. In both cases, $\mathrm{I}-\mathrm{V}$ curves were measured during a single day 
over a wide range of operating conditions using a DayStar (Model DS-100) curve tracer. Simultaneous measurements of module temperature and solar irradiance were also recorded. A reference temperature of $\mathrm{T}_{0}=50^{\circ} \mathrm{C}$ was selected somewhat arbitrarily but is representative of cell temperatures for typical flat-plate modules under PVUSA Test Conditions (2).

\section{Array Performance Characterization}

The steps used in analyzing the array performance measurements recorded were as follows:

1. Confirm calibration of all instruments and sensors used for field testing,

2. Correct POA, irradiance measurements, $\mathrm{E}$, for the pyranometer's AOI dependent calibration constant,

3. Calculate the cell temperature, $T_{c}$, using Equation (11),

4. Translate the measured values for $I_{s c}, I_{m p}, V_{o c}$, and $V_{m p}$ to a reference cell temperature, $T_{r}=50^{\circ} \mathrm{C}$, using Equations (12-15) and predetermined values for the temperature coefficients,

$$
\begin{gathered}
I_{s c}\left(50^{\circ} \mathrm{C}\right)=I_{s c}+\alpha_{I s c} E / E_{o}\left(50-T_{c}\right) \\
I_{m p}\left(50^{\circ} \mathrm{C}\right)=I_{m p}+\alpha_{I m p} E / E_{o}\left(50-T_{c}\right) \\
V_{o c}\left(50^{\circ} \mathrm{C}\right)=V_{o c}+\beta_{V o c}\left(50-T_{c}\right) \\
V_{m p}\left(50^{\circ} \mathrm{C}\right)=V_{m p}+\beta_{V_{m p}}\left(50-T_{c}\right)
\end{gathered}
$$

5. Calculate the $\mathrm{AM}_{\mathrm{a}}$ and AOI for each measurement using Equation (7) and Equation (9),

6. Adjust the $\operatorname{Isc}\left(50^{\circ} \mathrm{C}\right)$ values to $\mathrm{AM}_{\mathrm{a}}=1.5$ and $\mathrm{AOI}=0$ degrees by dividing by the predetermined $f_{1}\left(A_{2}\right)$ and $f_{2}(A O I)$ functions,

7. Plot $\mathrm{I}_{\mathrm{sc}}\left(50^{\circ} \mathrm{C}, \mathrm{AM}_{\mathrm{a}}=1.5, \mathrm{AOI}=0^{\circ}\right)$ versus POA irradiance and use a linear fit with zero intercept to obtain $\mathrm{I}_{\text {sco }}$ needed in Equation (1),

8. Calculate the effective irradiance, $E_{\mathrm{e}}$, for each measurement by dividing $\mathrm{I}_{\mathrm{sc}}\left(50^{\circ} \mathrm{C}\right)$ by $\mathrm{I}_{\mathrm{sco}}$,

9. Plot $\mathrm{I}_{\mathrm{mp}}\left(50^{\circ} \mathrm{C}\right)$ versus $\mathrm{E}_{\mathrm{e}}$ and use a linear fit with zero intercept to obtain $\mathrm{I}_{\mathrm{mpo}}$ needed in Equation (2),

10. Plot $V_{o c}\left(50^{\circ} \mathrm{C}\right)$ versus $\ln \left(E_{e}\right)$ and use a linear fit to obtain $V_{\text {oco }}$ and $C_{1}$ needed in Equation (3),

11. Plot $\mathrm{V}_{\mathrm{mp}}\left(50^{\circ} \mathrm{C}\right)$ versus $\ln \left(\mathrm{E}_{\mathrm{e}}\right)$ and use a $2^{\text {nd }}$ order polynomial fit to obtain $\mathrm{V}_{\text {mpo }}, \mathrm{C}_{2}$, and $\mathrm{C}_{3}$ needed in Equation (4), and

12. Use performance model to calculate array performance for any desired POA irradiance, cell temperature, absolute air mass, and angle-of-incidence. 
Figures 8-11 illustrate the results of applying the data analysis methodology to the ASE Americas crystalline silicon array. Figures 12-15 illustrate the results for the USSC triple-junction amorphous silicon array. In these figures, the measured values are shown along with the regression fits determined using the models described by Equations (1-5). The coefficients obtained from the regressions are the values needed in the performance model. In Figures 8 and 12, the irradiance indicated was corrected for the AOI-dependent behavior of the pyranometer.

The quality of the fits, the degree of linearity obtained, the zero intercepts for current versus irradiance, and the magnitude of the coefficient for $V_{o c}$ versus the logarithm of irradiance strongly indicate the validity of this performance characterization method. The model's versatility is illustrated by the success achieved for two distinctly different technologies under a wide range of operating conditions; irradiance from 100 to $1200 \mathrm{~W} / \mathrm{m}^{2}$, operating temperature from 10 to $65^{\circ} \mathrm{C}$, absolute air mass from 7 to 0.9 , and angle-of-incidence from 0 to $75^{\circ}$. Figures 11 and 15 illustrate the measured $P_{m p}$ compared to $P_{m p}$ from the performance model over the duration of the test period at both sites.

\section{CONCLUSIONS}

The new performance characterization methodology described in this paper will enable the photovoltaic industry and its customers to accurately determine the performance of photovoltaic modules and arrays for all operating conditions. The methods can be used to design a new system, to rate the performance of an array after installation, to continuously monitor actual performance of an array relative to its anticipated performance, and to help evaluate the efficiency of power conditioning systems. For the first time, the method developed handles the influences of irradiance, temperature, solar spectrum, solar angle-of-incidence, and temperature coefficients in a practical yet rigorous way. The uncertainty in array performance rating has been reduced from perhaps $\pm 10 \%$ to about $\pm 3 \%$, and the predictive model developed can be used to calculate an "energy rating" for a module or array.

\section{ACKNOWLEDGEMENTS}

A number of people have contributed significantly to the effort documented in this paper. The author is particularly grateful for the contributions of Jay Kratochvil and Bill Boyson (Sandia), Chuck Whitaker (Endecon Engineering), Pete Eckert (Arizona Public Service), and Steve Durand and Abraham Ellis (SW Technology Development Institute). 


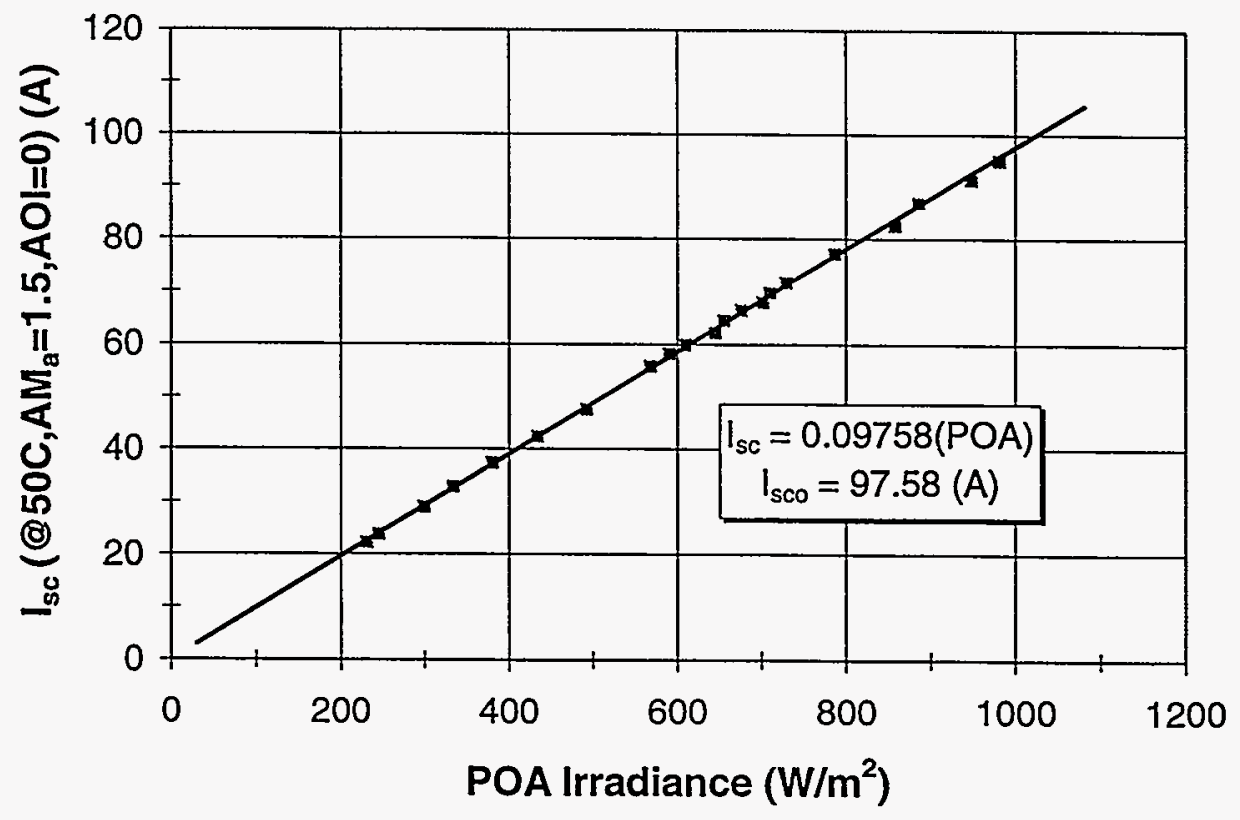

FIGURE 8. Measured $l_{\mathrm{sc}}$ for $25-\mathrm{kW}$ array of ASE Americas ASE-300-DG/50 modules. $I_{\mathrm{sc}}$ is plotted versus the POA irradiance, $E$.

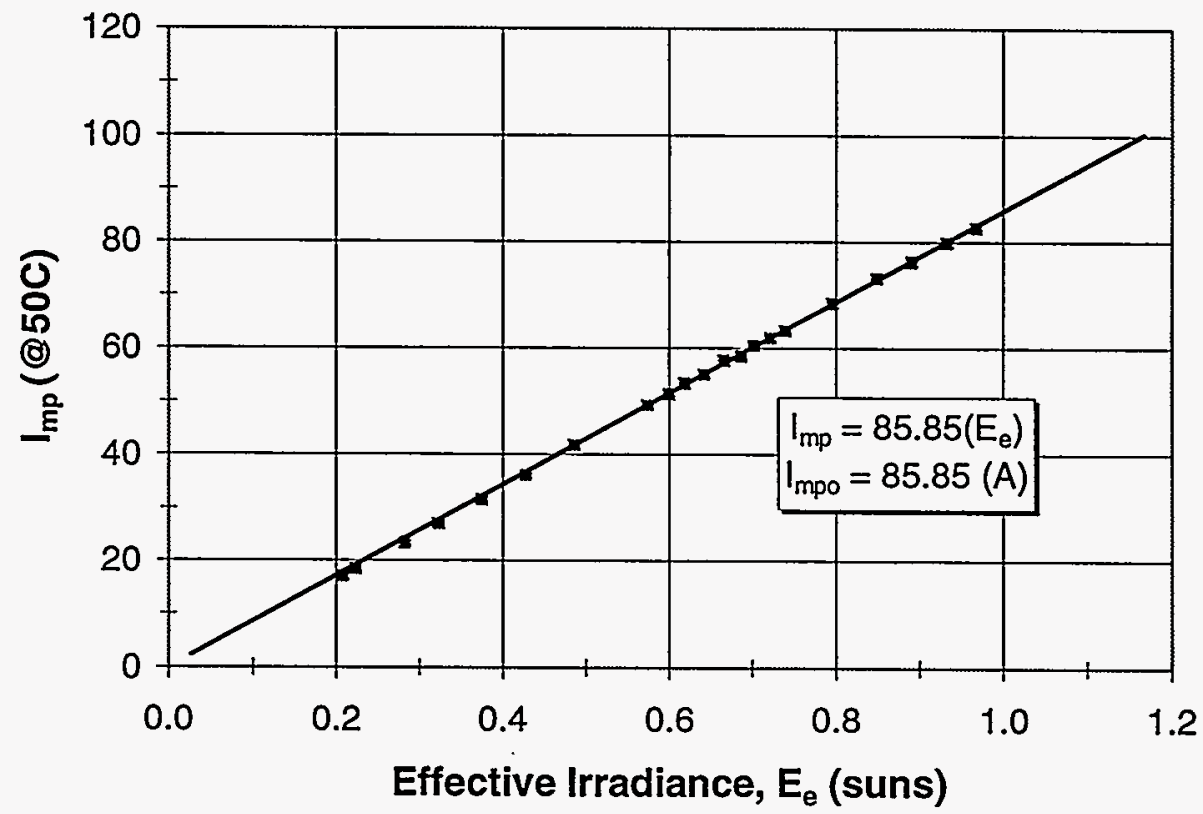

FIGURE 9. Measured $I_{m p}$ for 25-kW array of ASE Americas ASE-300-DG/50 modules. $I_{m p}$ is plotted versus the effective irradiance, $E_{\mathrm{e}}$. 


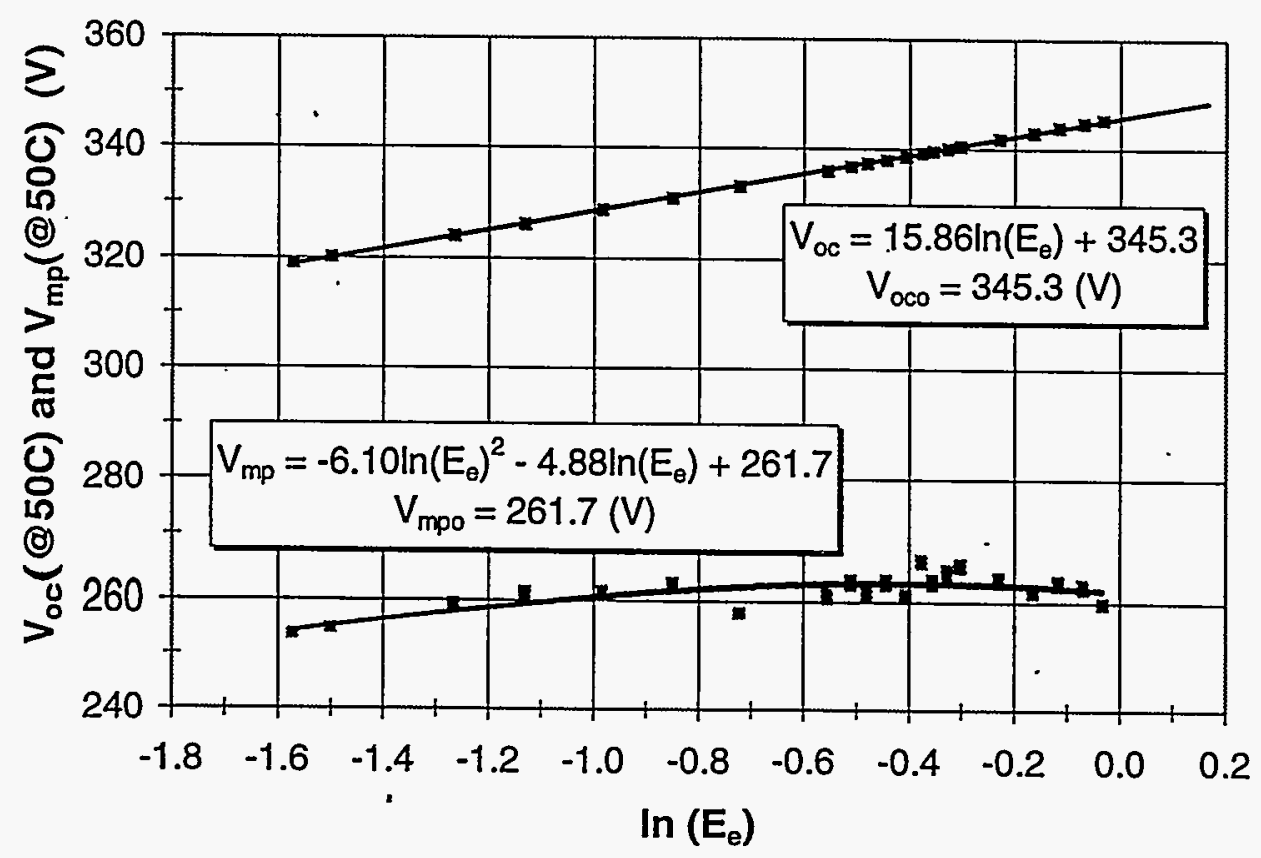

FIGURE 10. Measured $V_{o c}$ and $V_{m p}$ for $25-k W$ array of ASE Americas ASE-300-DG/50 modules including regression fits to measurements.

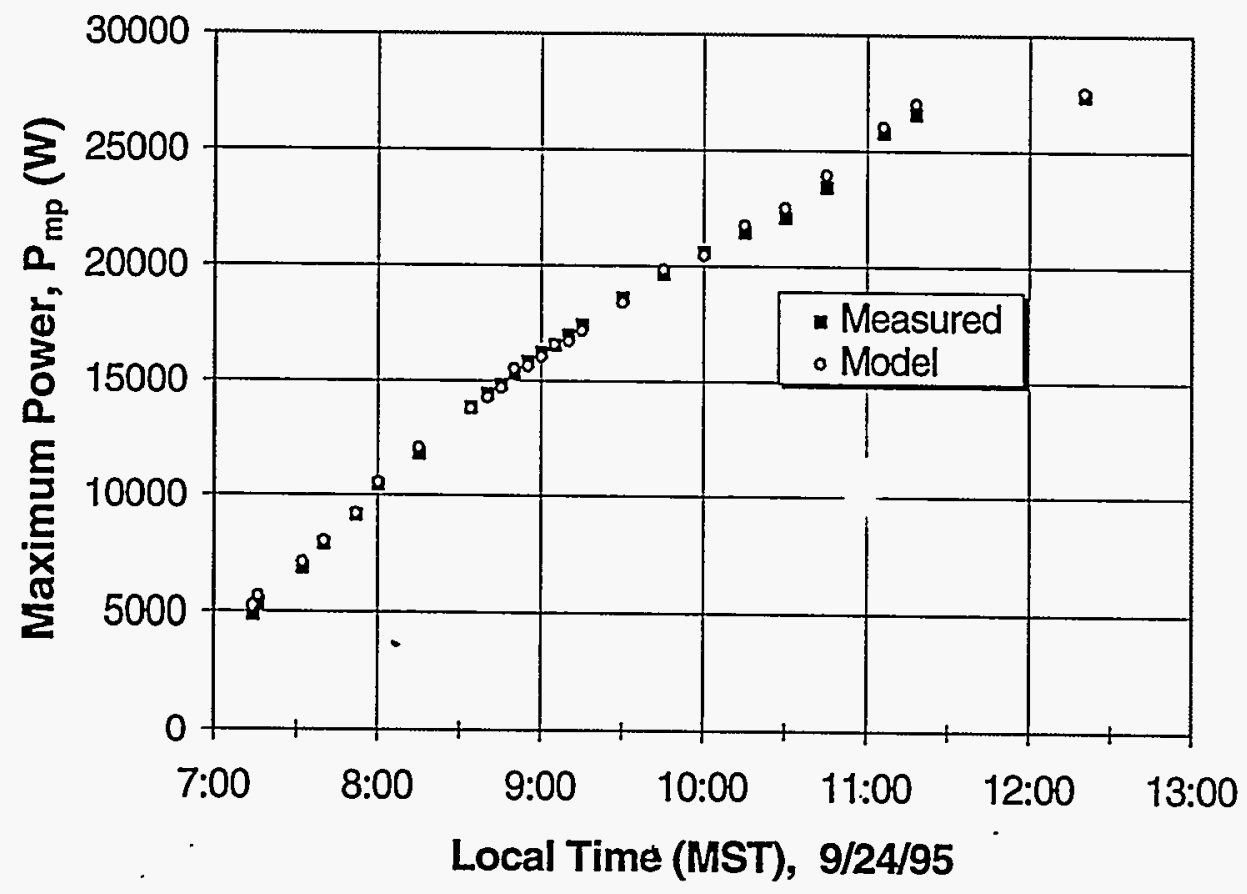

FIGURE 11. Measured $P_{m p}$ for 25-kW array of ASE Americas ASE-300-DG/50 modules . compared to $P_{m p}$ given by the performance model. 


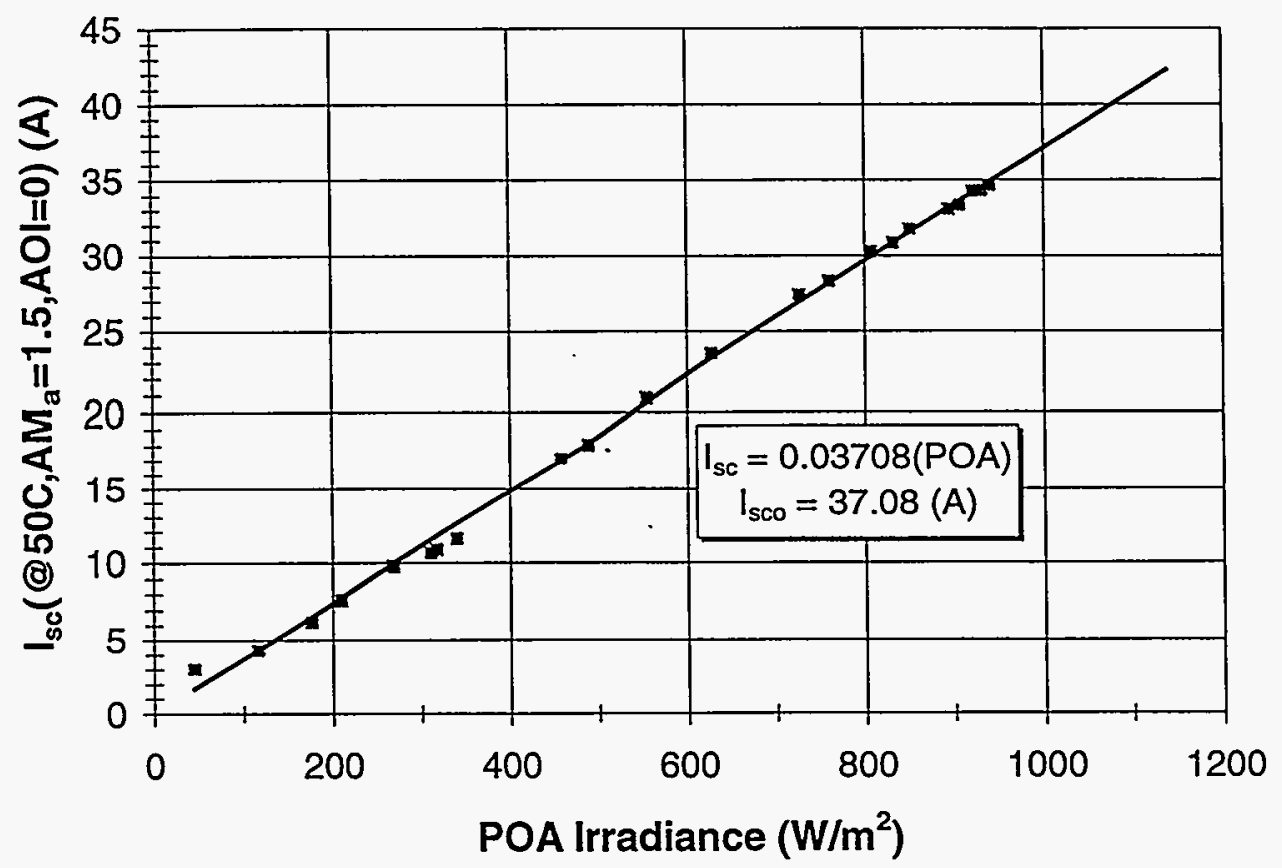

FIGURE 12. Measured $\mathrm{I}_{\mathrm{sc}}$ for $1.2-\mathrm{kW}$ array of USSC triple-junction amorphous silicon modules. $I_{s c}$ is plotted versus the POA irradiance, $E$.

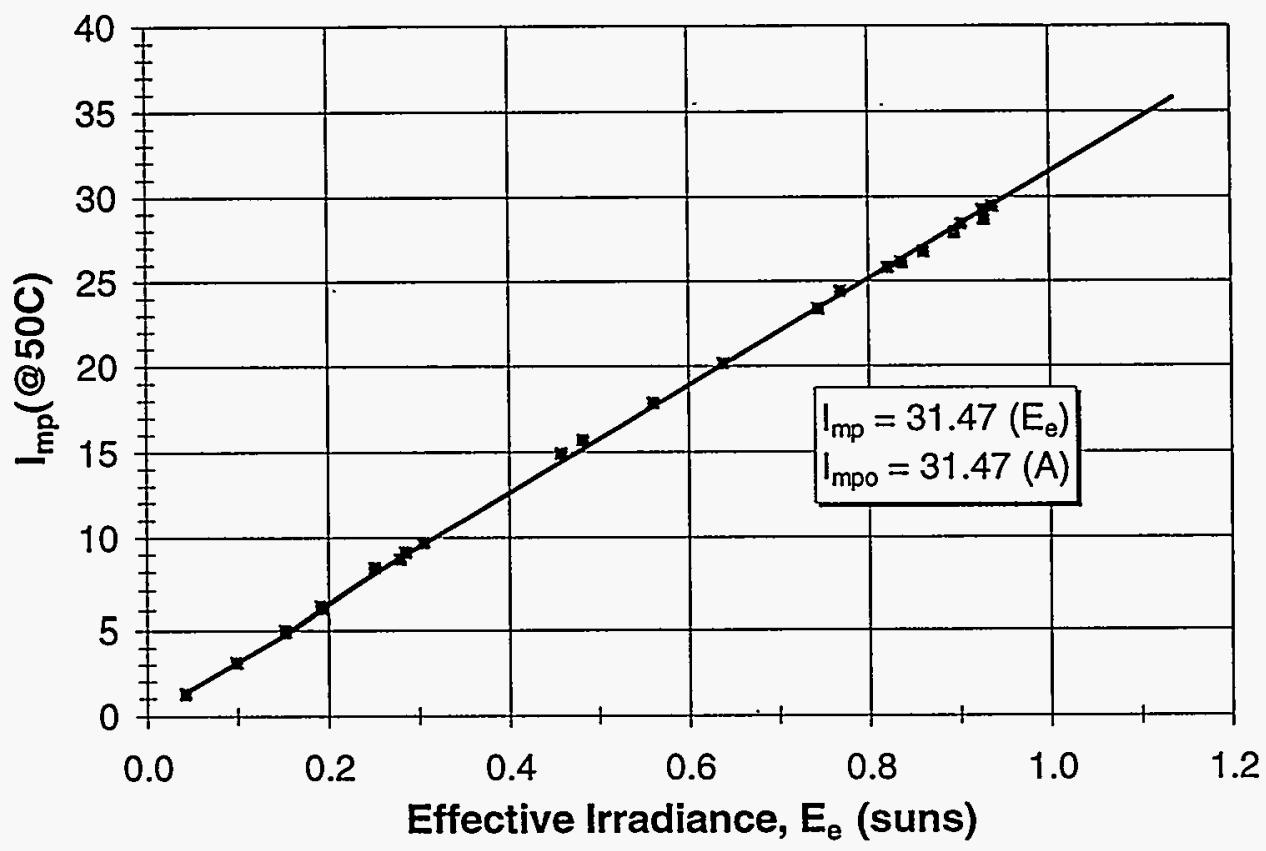

FIGURE 13. Measured $I_{\mathrm{mp}}$ for $1.2-\mathrm{kW}$ array of USSC triple-junction amorphous silicon modules. $I_{m p}$ is plotted versus the effective irradiance, $E_{e}$. 


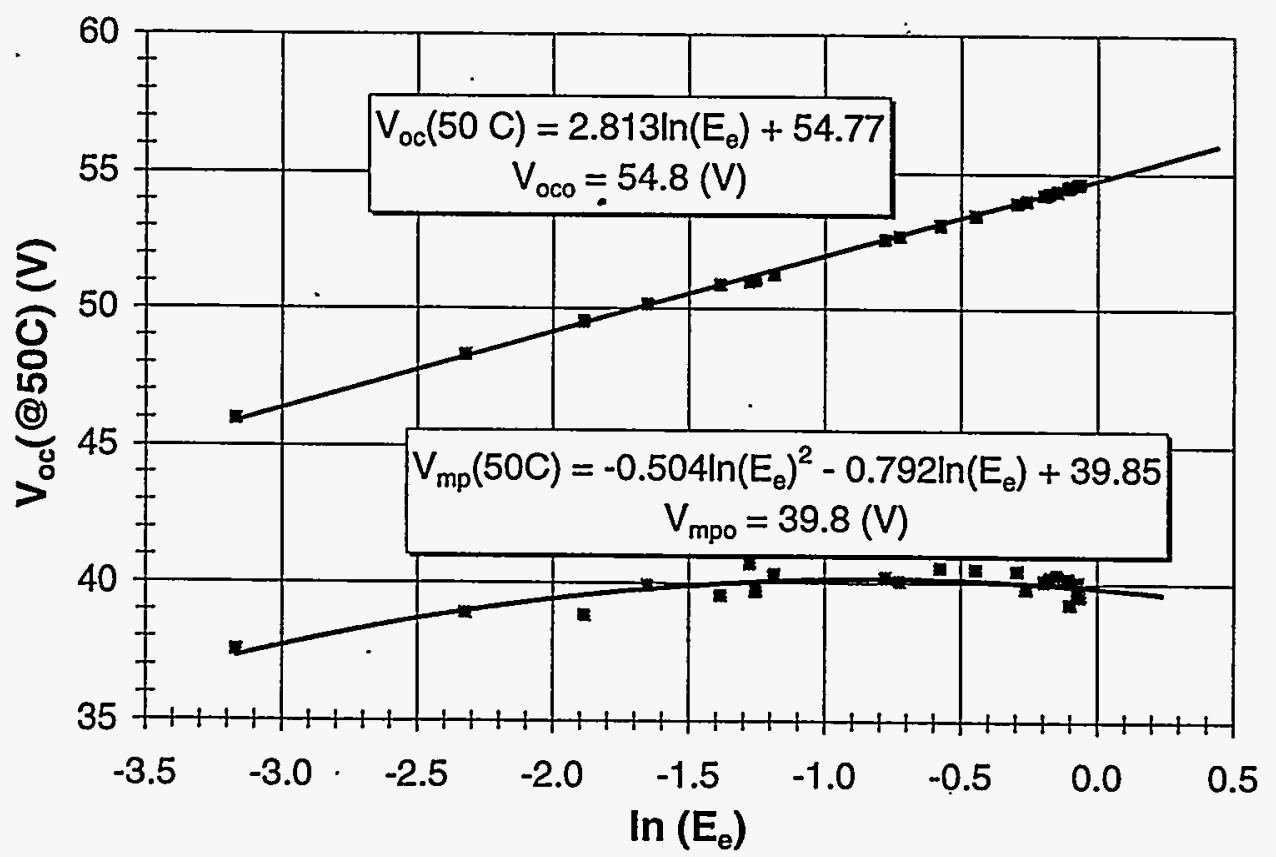

FIGURE 14. Measured $V_{o c}$ and $V_{m p}$ for 1.2-kW array of USSC triple-junction amorphous silicon modules, including regression fits to measurements.

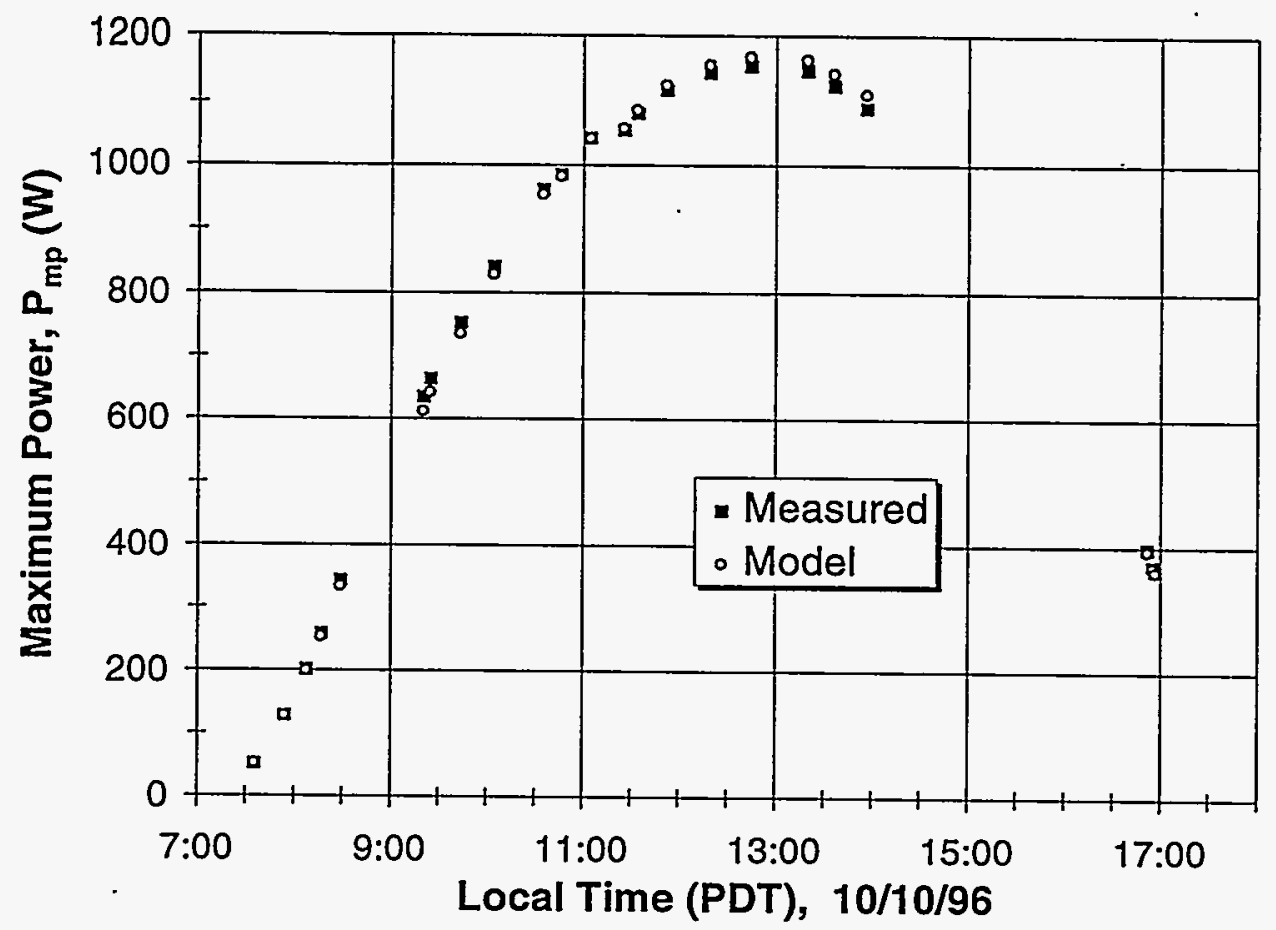

FIGURE 15. Measured $P_{m p}$ for 1.2-kW array of USSC triple-junction amorphous silicon modules compared to $P_{m p}$ given by the performance model. 


\section{REFERENCES}

1. ASTM E 1036, "Standard Methods for Testing Electrical Performance of Nonconcentrator Terrestrial PV Modules and Arrays Using Reference Cells."

2. T. Candelario, et al, "PVUSA - Performance, Experience, and Cost," 22nd IEEE PVSC, Oct. 1991, pp. 493-500.

3. C. M. Whitaker, et.al., "Effects of Irradiance and Other Factors on PV Temperature Coefficients," $22^{\text {nd }}$ IEEE PVSC, Oct. 1991, pp. 608-613.

4. T. Townsend, et al, "A New Performance Index for PV System Analysis," 24th IEEE PVSC, Dec. 1994, pp. 1036-1039.

5. A. Rosenthal, M. Thomas, and S. Durand, "A Ten Year Review of Performance of Photovoltaic Systems," 23rd IEEE PVSC, May 1993, pp. 1289-1291.

6. ASTM E 1039, "Standard Method for Calibration and Characterization of Non-Concentrator Terrestrial Photovoltaic Reference Cells Under Global Irradiation."

7. ASTM E 1144, "Standard Method for Calibration of Non-Concentrator Terrestrial Photovoltaic Primary Reference Cells Under Direct Irradiance."

8. B. Kroposki, et.al., "Photovoltaic Module Energy Rating Methodology Development," $25^{\text {th }}$ IEEE PVSC, May 1996, pp. 1311-1314.

9. R. L. Hulstrom, editor, Solar Resources, MIT Press, Cambridge, 1989, ch. 5, pp. 174-308.

10. M. S. Imamura, et.al, "Assessment of Simplified Outdoor Calibration Methods for Solar Irradiance Sensors," 11th European PSEC Conference, 1992, pp. 1638-1643.

11. ASTM E 941, "Standard Test Method for Calibration of Reference Pyranometers With Axis Tilted by Shading Method."

12. ASTM E 1125, "Standard Test Method for Calibration of Silicon Non-Concentrator Terrestrial Photovoltaic Reference Cells Using a Tabular Spectrum."

13. I. Zanesco and A. Krenzinger, "The Effects of Atmospheric Parameters on the Global Solar Irradiance and on the Current from a Silicon Solar Cell," Progress in Photovoltaics, Vol. 1, pp. 169-179, 1993.

14. F. Kasten and A. Young, Applied Optics, 28, 4735-4738 (1989).

15. ASTM E 892, "Tables for Terrestrial Solar Spectral Irradiance at Air Mass 1.5 for $37^{\circ}$ Tilted Surface."

16. ASTM E 973, "Test Method for Determination of a Spectral Mismatch Parameter Between a Photovoltaic Device and a Photovoltaic Reference Cell."

17. C. Helmke, W. Zaaiman, and H. Ossenbrink, "An Assessment of the Results of Calibrating 600 Silicon PV Reference Devices," $25^{\text {th }}$ IEEE PVSC, May 1996, pp. 1267-1270.

18. C. Leboeuf and H. Ossenbrink, "PV Module Power Output: Sensitivity and Uncertainty in Non-STC Measurements," $22^{\text {nd }}$ IEEE PVSC, Oct. 1991, pp. 614-619.

19. M. K. Fuentes, "A Simplified Thermal Model for Flat-Plate Photovoltaic Arrays," Sandia Report, SAND85-0330, May 1987. 